Abstracta Iranica Abstracta Iranica

Revue bibliographique pour le domaine irano-aryen

Volume 30 | 2010

Comptes rendus des publications de 2007

\title{
For the Privileged Few: Islamic Miniature Painting from the David Collection. Copenhagen, Lousiana Museum of Modern Art, The David Collection, 2007, 236 p.
}

\section{Karin Rührdanz}

\section{(2) OpenEdition}

1 Journals

\section{Édition électronique}

URL : http://journals.openedition.org/abstractairanica/37829

DOI : 10.4000/abstractairanica.37829

ISSN : 1961-960X

Éditeur :

CNRS (UMR 7528 Mondes iraniens et indiens), Éditions de l'IFRI

\section{Édition imprimée}

Date de publication : 8 avril 2010

ISSN : 0240-8910

\section{Référence électronique}

Karin Rührdanz, «For the Privileged Few: Islamic Miniature Painting from the David Collection.

Copenhagen, Lousiana Museum of Modern Art, The David Collection, 2007, 236 p. », Abstracta Iranica [En ligne], Volume 30 | 2010, document 175, mis en ligne le 08 avril 2010, consulté le 27 septembre 2020. URL : http://journals.openedition.org/abstractairanica/37829; DOI : https://doi.org/10.4000/ abstractairanica.37829

Ce document a été généré automatiquement le 27 septembre 2020.

Tous droits réservés 


\title{
For the Privileged Few: Islamic Miniature Painting from the David Collection. Copenhagen, Lousiana Museum of Modern Art, The David Collection, 2007, $236 \mathrm{p}$.
}

\author{
Karin Rührdanz
}

1 This Book (also published in Danish) documents an exhibition of 132 miniature paintings from the David Collection presented in Copenhagen in 2007. At that time, the David Collection owned 19 illustrated manuscripts and 447 dispersed or single sheet paintings and drawings, with additional material on loan from other Danish institutions. These numbers include the recent acquisition of the Benkaim Collection that made miniatures the most important section of the David Collection.

2 Written for an interested public not familiar with Islamic art, the introduction touches on fundamental problems, as aniconism and specifics of patronage, gets the reader informed about the art of the book in Islamic lands and its technical aspects, and traces the formation of the painting collection. The catalogue is chronologically arranged and divided into three parts followed by an epilog dealing with the period from 1750-1850, a selected bibliography, a map and a table of Islamic dynasties.

3 The excellent large colour reproductions mostly show the complete leaf. In those cases where only the miniature, or a detail, is presented, a small picture of the leaf is added. The accompanying label contains the basic information only while a contextual discussion of the individual object takes place in the text introducing each part.

4 The 132 exhibits cover all periods and regions of Islamic miniature painting, but do so unevenly. This is most felt for «The Formative Period, c. 1200-1500» where the 32 items cannot adequately reflect the diversity of three centuries of artistic development. Among them, however, are not only very fine specimen but also items which will challenge research, as the early copy of 'Ațtāă's Manțeq al-țeyr will surely do. "The 
Classical Period, c. 1500-1600» (43 objects) includes examples of the two famous dispersed courtly Šāh-nāmes and a second enigmatic Falnama leaf, depicting the «Azure monastery ». The third part, « The New Age, c. 1600-1750» (45 objects) focuses on the new developments: the interest in the individual whether human, animal or plant, the artistic experiments under the influence of foreign models whether European or from neighbouring countries, and the change in patronage.

5 The high quality of the items selected for this exhibition sets expectation high for the opening of the renovated and newly arranged galleries of the David Collection in 2009 when it will house the largest show of Islamic miniature painting permanently accessible to the public.

INDEX

Thèmes : 5.0. Généralités

\section{AUTEURS}

KARIN RÜHRDANZ

Royal Ontario Museum - Toronto 